International Journal of Library \& Information Science (IJLIS)

Volume 8, Issue 1, January-April 2019, pp. 35-40, Article ID: IJLIS_08_01_004

Available online at

http://iaeme.com/Home/issue/IJLIS?Volume=8\&Issue $=1$

Journal Impact Factor (2019): 9.8614 (Calculated by GISI) www.jifactor.com

ISSN Print: 2277-3533 and ISSN Online: 2277-3584

(C) IAEME Publication

\title{
USE OF ELECTRONIC RESOURCES BY RESEARCH SCHOLARS OF LIFE-SCIENCES, KUVEMPU UNIVERSITY, SHANKARAGHATTA, SHIVAMOGGA: A STUDY
}

\author{
Girimallesh H. N. \\ Department of Library and Information Science, Karnatak University, Dharwad, India \\ *E-mail: girishhn98@gmail.com; numurthy60@yahoo.co.in
}

\begin{abstract}
Electronic resources (E-resources) have become the most sought after library reserves, in satisfying the varied needs of patrons expeditiously. Information technology has brought phenomenal change and has become an important tool for information dissemination, storing and retrieving, as a result E-Information sources have acquired major portion of library collection. The present study has been chosen on use of E-resources by the life science research scholars of Kuvempu University, Shivamogga to verify how E-resources have brought changes in the progress of research and development and what are the constrains in transforming print mode of library to digital library and seek possible suggestions for the improvement in library resources. The results revealed the electronic are quite useful to research scholars of life sciences and these are good alternatives compared conventional print resources or hard copies. Digitalization of agricultural university libraries is quite useful for dissemination of knowledge among biological science research scholars.
\end{abstract}

Key words: Biological sciences, E-resources, Kuvempu University, Knowledge dissemination

Cite this Article: Girimallesh H. N., Use of Electronic Resources by Research Scholars of Life-Sciences, Kuvempu University, Shankaraghatta, Shivamogga: A Study, International Journal of Library \& Information Science, 8(1), 2019, pp. 35-40. http://iaeme.com/Home/issue/IJLIS?Volume=8\&Issue=1

\section{INTRODUCTION}

The rapid advancement in Information and communications technology (ICT) has brought transformational changes in the information scenario and has given rise to a number of options to handle verified information sources conveniently and effortlessly. Today's libraries are shifting their role from the custodian of traditional information resources to the provider of service-oriented digital information resources. Widespread use of computers, increased 
reliance on computer networks, rapid growth of Internet and explosion in the quality, and quantity of information compelled libraries to adopt new means and methods for the storage, retrieval and dissemination of information.

E-resources have become the most sought after library reserves, in satisfying the varied needs of patrons expeditiously. Information technology has changed the way world functions and has become an important tool for information dissemination, storing and retrieving. As a result E-Information sources have acquired major portion of library collection. Also we are seeing that E-resources over web have become an invaluable tool for learning, teaching and research.

\subsection{Need for the study}

At present the libraries are moving from the traditional print sources to dynamic and more flexible E-resources and providing easy access to all the users of library. With this concern the present study has been selected on use of E- Resources by the life science research scholars of Kuvempu University, Shivamogga.

\subsection{Objectives of the study}

The main objectives of the study are to investigate and unfold awareness, utilization level of e-resources and services by life science research scholars of Kuvempu Univeristy, Shivamogga, India.

- To find out the level of awareness among research scholars on E-resources.

- To find out the frequency of use of E-resources.

- To identify user requirements and priorities of network based e-resources.

- To find out the problems faced by the research scholars while accessing and use of Eresources.

- To analyze the research scholars dependency on E-resources.

- To identify place from which the research scholars access e-resources and to unmask the satisfaction regarding the infrastructure facility and e-resources available to them.

\section{METHODOLOGY}

A questionnaire method is followed for the present study to explore and collect the data from research scholars of Life science departments of Kuvempu Univeristy, Shivamogga.

\section{ANALYSIS AND INTERPRETATION}

\subsection{Gender wise distribution of respondents}

The gender wise distribution of respondents is given in Table 1, of the total 60 respondents surveyed $123(68.33 \%)$ were male and $57(31.66 \%)$ were female. The data suggest that majority of biological researchers were male dominant community.

Table 1 Gender-wise respondents

\begin{tabular}{|c|c|c|c|}
\hline $\begin{array}{c}\text { Sl. } \\
\text { No. }\end{array}$ & Gender & No. of respondents & Percent \\
\hline 1 & Male & 123 & $68.33 \%$ \\
\hline 2 & Female & 57 & $31.66 \%$ \\
\hline
\end{tabular}


Use of Electronic Resources by Research Scholars of Life-Sciences, Kuvempu University, Shankaraghatta, Shivamogga: A Study

\subsection{Age wise distribution of respondents}

The age wise distribution respondents is presented in Table 2, and majority of respondents were in the age group of $21-23$ years $(58.33 \%)$, followed by $24-26$ years and above $(33.33 \%)$ and 26 years and above (8.33\%). Majority of respondents are youngsters.

Table 2 Age-wise respondents

\begin{tabular}{|c|c|c|c|}
\hline Sl. No. & Age & No. of respondents & Percent \\
\hline 1 & Below 21-23 & 105 & $58.33 \%$ \\
\hline 2 & $24-26$ & 60 & $33.33 \%$ \\
\hline 3 & 26 and above & 15 & $8.33 \%$ \\
\hline
\end{tabular}

\subsection{Frequency of use of e-resources}

Data on usage of e-resources by respondents is presented in Table 3. One hundred and eveven $(61.66 \%)$ respondents are using e-resources on daily basis followed by $21.81 \%$ of research scholars use e-resources 2-3 times a week. Less frequency of researchers uses e-resources 2-3 times in a month (10.90\%) and once in a month $(9.09 \%)$.

Table 3 Frequency of E-resources used by respondents

\begin{tabular}{|c|l|c|c|}
\hline Sl. No. & \multicolumn{1}{|c|}{ Frequency of usage } & Number & Percent \\
\hline 1 & Daily & 111 & $61.66 \%$ \\
\hline 2 & $2-3$ times a week & 36 & $21.81 \%$ \\
\hline 3 & $2-3$ times a month & 18 & $10.90 \%$ \\
\hline 4 & Once in a month & 15 & $9.09 \%$ \\
\hline
\end{tabular}

\subsection{Location of e-resources used by respondents}

Majority of research scholars use e-resources in the department where they are working $(80.00 \%), 16.66 \%$ of researchers also use e-resources in the university library (Table 4$)$. Less percentage of students (3.3\%) access e-resources at the cyber café or Browsing centers.

Table 4 Location of E-resources used by respondents

\begin{tabular}{|c|l|c|c|}
\hline Sl. No. & \multicolumn{1}{|c|}{ Location of usage } & Number & Percent \\
\hline 1 & University Library & 30 & $16.66 \%$ \\
\hline 2 & Department & 144 & $80.00 \%$ \\
\hline 3 & Cybercafé/Browsing Center & 06 & $3.3 \%$ \\
\hline
\end{tabular}

\subsection{Types of e-resources used by respondents to locate information}

Analysis reveals that majority of biological science research scholars $(88.30 \%)$ use e-journals and $5 \%$ use e-thesis and e-dissertation. 3.3\% of scholars e-books and e-databases respectively (Table 5).

Table 5 Types of E-resources used by respondents

\begin{tabular}{|c|l|c|c|}
\hline SI. No. & \multicolumn{1}{|c|}{ Types of E-resources used } & Number & Percent \\
\hline 1 & E-Journals & 159 & $88.3 \%$ \\
\hline 2 & E-databases & 06 & $3.3 \%$ \\
\hline 3 & E-books & 06 & $3.3 \%$ \\
\hline 4 & E-theses and dissertation & 09 & $5.0 \%$ \\
\hline
\end{tabular}




\subsection{Preference of e-resources used by respondents}

Data on preference of e-resources used by biological science research scholars is presented in Table 6 . One hundred fifty three $(85.00 \%)$ research scholars use online resources including ejournals and e-books. Less frequency of researchers also use print $(8.3 \%)$ and audiovisual materials $(6.6 \%)$.

Table 6 Preference of E-resources used by respondents

\begin{tabular}{|c|l|c|c|}
\hline Sl. No. & \multicolumn{1}{|c|}{ Preference } & Number & Percent \\
\hline 1 & Print Sources & 15 & $8.3 \%$ \\
\hline 2 & Audio-visual material (CD and DVD) & 12 & $6.6 \%$ \\
\hline 3 & $\begin{array}{l}\text { Online resources (E-Journals/Databases/E- } \\
\text { books) }\end{array}$ & 153 & $85.0 \%$ \\
\hline
\end{tabular}

\subsection{Purpose of using e-resources}

Data revels that $58.3 \%$ of researchers use e-resources for finding the information in the area of specialization, $33.3 \%$ of biological research scholars use e-resources to get information in the area of research. Similarly, $8.3 \%$ of researchers used e-resources to update their knowledge (Table 7).

Table 7 Purpose of E-resources used by respondents

\begin{tabular}{|c|l|c|c|}
\hline Sl. No. & \multicolumn{1}{|c|}{ Purpose } & Number & Percent \\
\hline 1 & $\begin{array}{l}\text { For finding relevant information in the area of } \\
\text { specialization }\end{array}$ & 105 & $58.3 \%$ \\
\hline 2 & For updating knowledge & 15 & $8.3 \%$ \\
\hline 3 & For getting information in the area of research & 60 & $33.3 \%$ \\
\hline
\end{tabular}

\subsection{Awareness of varied E-resources available in the areas of biological sciences}

Survey data on the awareness of e-resources in the area of biological sciences, $53.33 \%$ are aware of web of science, $43.33 \%$ are aware of scopus, $71.66 \%$ are aware of Science Direct and $35.0 \%$ are aware of J-stor (Table 8 ).

Table 8 Awareness of varied E-resources available in the areas of biological sciences

\begin{tabular}{|c|l|c|c|c|c|c|}
\hline $\begin{array}{c}\text { Sl. } \\
\text { No. }\end{array}$ & \multicolumn{1}{|c|}{ Particulars } & BIOONE & $\begin{array}{c}\text { WEB OF } \\
\text { SCIENCE }\end{array}$ & SCOPUS & $\begin{array}{c}\text { SCIENCE } \\
\text { DIRECT }\end{array}$ & J-stor \\
\hline 1 & $\begin{array}{l}\text { Awareness of } \\
\text { different E- } \\
\text { resources in the } \\
\text { field of } \\
\text { biological } \\
\text { sciences }\end{array}$ & $07(11.66 \%)$ & $32(53.33 \%)$ & $26(43.33 \%)$ & $43(71.66 \%)$ & $21(35 \%)$ \\
& & & & & \\
\hline
\end{tabular}

\subsection{Overall satisfactions of E-resources in research and academic efficiency of biological scientists}

Survey data disclosed that $38.3 \%$ of biological science researchers are fully satisfied with eresources, $46.6 \%$ are partially satisfied, and $6.6 \%$ are least satisfied (Table 9). 
Use of Electronic Resources by Research Scholars of Life-Sciences, Kuvempu University, Shankaraghatta, Shivamogga: A Study

Table 9 Overall satisfactions of E-resources in research and academic efficiency of biological scientists

\begin{tabular}{|c|l|c|c|}
\hline Sl. No. & \multicolumn{1}{|c|}{ Satisfaction } & Number & Percent \\
\hline 1 & Fully satisfied & 69 & $38.3 \%$ \\
\hline 2 & Partially satisfied & 84 & $46.6 \%$ \\
\hline 3 & Least satisfied & 12 & $6.6 \%$ \\
\hline 4 & Cannot say & 15 & $8.3 \%$ \\
\hline
\end{tabular}

\subsection{Impact of E-resources in research of biological scientists}

Survey analysis showed that $58.33 \%$ of biological science researchers fully agree that eresources had most impact on their research. $41.66 \%$ of researchers strongly agree that eresources quite useful in their research (Table 10).

Table 10 Impact of E-resources in research of biological scientists

\begin{tabular}{|c|l|c|c|}
\hline Sl. No. & Impact of E-resources in research work & Number & Percent \\
\hline 1 & Strongly Agree & 75 & $41.66 \%$ \\
\hline 2 & Agree & 105 & $58.33 \%$ \\
\hline
\end{tabular}

\subsection{Problems faced while accessing E-resources}

Respondents were enquired to give their opinion on problems faced by them while accessing e-resources and data is given in Table 11. Majority of researchers $(78.33 \%)$ slow internet speed was main problem in accessing e-resources. Similarly, $48.33 \%, 21.66 \% 18.33 \%$ of researchers are opined that proxy server problem, lack of information literacy and no proper guidance and training respectively were the factors in hindering access of e-resources.

Table 11 Problems faced while accessing E-resources

\begin{tabular}{|l|c|c|}
\hline \multicolumn{1}{|c|}{ Particulars } & Number & Percent \\
\hline Slow internet speed & 47 & $78.33 \%$ \\
\hline Lack of ICT infrastructure & 05 & $8.33 \%$ \\
\hline Lack of information literacy & 13 & $21.66 \%$ \\
\hline Incomplete subject coverage & 08 & $13.33 \%$ \\
\hline Proxy server problem & 29 & $48.33 \%$ \\
\hline No proper guidance and training & 11 & $18.33 \%$ \\
\hline
\end{tabular}

\section{FINDINGS OF THE STUDY}

The survey data reveals that $61.66 \%$ of biological researchers use e-resources on daily basis and majority of them $(80.0 \%)$ access e-resources in department where they are working. $88.3 \%$ of researchers used e-journals and then e-books (3.3\%). Majority of biological science research scholars use e-resources to find relevant information in the area of specialization. Biological science researchers are aware of famous e-resource sites such as Web of Science, Scopus, Science Direct and J-stor. $38.3 \%$ and $56.6 \%$ of researchers are fully and partially satisfied in usage of e-resources.

$58.33 \%$ of researchers agree that e-resources had strong impact on their knowledge, research capability. However, majority of the researchers fell that slow internet facility is the hindrance in successful usage of e-resources. The above findings are concurrence with opinion given by researchers of the other fields (Farahi and Gandhi, 2011). Similar to the current survey Hadagali and Kumbar (2011) and Hussain and Ansari (2010) conducted survey 
on usage of e-resources and strongly support the usefulness of e-resources in academics and research.

\section{RECOMMENDATIONS AND CONCLUSION}

It is evident from the current study that e-resources should be integral part of University and college libraries and are useful in accessing information. It is recommended the authorities of Kuvempu University to facilitate high-speed computer terminals at university library, departments, and research institutes. The library web page should be designed in such a way that it should provide information and guidelines for utilization of e-resources. University library personnel should conduct short term training course on ways, means and procedures to access e-resources.

\section{REFERENCES}

[1] Farahi, M.T. \& Ansari, M.M.A. (2010). Utilization of e-information resources in medical colleges: A case study. SRELS Journal of Information Management, 48: 281-288

[2] Hadagali, G.S. \& Kumbar, B.D. (2011). Use of electronic resources in university libraries of Karnataka state. Information Studies, 17: 211-224.

[3] Hussain, A. \& Ansari, M.M.A. (2010). User perception of usability of e-resources at IMT, Gaziabad: A case study. Gyanakosh: The Journal of Library and Information Management, 1: 31-47.

[4] Manorama Tripathi \& Jeevan, V.K.J. (2013). A selective review of research on eresources usage in academic libraries. Library Review, 62: 134-156.

[5] Sampth Kumar, P.T. \& Kumar, G.T. (2010). Perception and usage of e-resources and internet by Indian academics. The Electronic Library, 28: 137-156. 